\title{
Deformation of nickel-titanium closed coil springs: an in vitro study
}

Camilla Ivini Viana Vieiraํㅜ, José Maurício dos Santos Nunes Reis², Luiz Geraldo Vaz², Lídia Parsekian Martins ${ }^{4}$, Renato Parsekian Martins ${ }^{5}$

DOI: http://dx.doi.org/10.1590/2177-6709.22.1.038-046.oar

Objective: The aim of this paper was to determine the amount of deformation in four commercial brands of nickeltitanium closed springs. Methods: A total of 130 springs were divided into 13 subgroups, according to their features and manufacturers (Morelli, Orthometric, Ormco and GAC) and activated from 100\% to 1000\% of the effective length of the nickel-titanium portion present at the spring, at $37^{\circ} \mathrm{C}$. Deactivation data were plotted and deformation was found graphically. The values were compared by analysis of variance and Tukey's post-hoc test. Results: Springs manufactured by Morelli had the same amount of deformation when they were activated up to $700 \%$ of Y activation; springs by Orthometric had the same amount of deformation up to 600-700\% of Y; springs by Ormco had the same amount of deformation up to $700-800 \%$ of Y; and finally, the majority of springs by GAC had similar deformation up to $800 \%$ $1000 \%$ of activation. All springs tested could be activated up to $700 \%$ without rupture. Conclusions: Most subgroups were similarly deformed up to $700 \%$ of activation, without rupture of springs. Subgroups 4B, 4C, 4D and 4E showed the same amount of deformation up to $1000 \%$ of activation without any rupture at all.

Keywords: NiTi. Deformation. Biomechanics.

Objetivo: o objetivo desse trabalho foi determinar a deformação em molas fechadas de níquel-titânio de quatro marcas comerciais. Métodos: cento e trinta molas foram divididas em treze subgrupos, de acordo com suas características e fabricantes (Morelli, Orthometric, Ormco e GAC), com ativação entre 100\% e 1.000\% do comprimento efetivo de níquel-titânio presente na mola $(\mathrm{Y})$, a $37^{\circ} \mathrm{C}$. Dados de desativação foram coletados e a deformação foi obtida de forma gráfica. Os valores foram comparados por meio de análise de variância e teste post-hoc de Tukey. Resultados: as molas da Morelli apresentaram a mesma quantidade de deformação considerando-se 700\% de ativação de Y; as molas da Orthometric tiveram a mesma quantidade de deformação até 600-700\% de Y; as molas da Ormco tiveram a mesma quantidade de deformação até 700-800\% de Y; e, por fim, a maioria das molas da GAC apresentou deformação semelhante até $800-1.000 \%$ de ativação. Todas as molas testadas puderam ser ativadas até 700\% sem ruptura. Conclusões: a maioria dos subgrupos se deformou de maneira semelhante até 700\% de ativação, sem ruptura das molas. Os subgrupos 4B, 4C, 4D e 4E demonstraram a mesma quantidade de deformação até $1.000 \%$ de ativação, sem nenhuma ruptura.

Palavras-chave: NiTi. Deformação. Biomecânica.

${ }^{1} \mathrm{MSc}$, Universidade Estadual Paulista (UNESP), Department of Pediatric Dentistry, School of Dentistry, Araraquara, São Paulo, Brazil.

${ }^{2}$ Assistant Professor, Universidade Estadual Paulista (UNESP), Department of Dental Material, School of Dentistry, Araraquara, São Paulo, Brazil.

${ }^{3}$ Full Professor, Universidade Estadual Paulista (UNESP), Department of Dental Material, School of Dentistry, Araraquara, São Paulo, Brazil.

${ }^{4}$ Assistant Professor, Universidade Estadual Paulista (UNESP), Department of Pediatric Dentistry, School of Dentistry, Araraquara, São Paulo, Brazil.

${ }^{5}$ Private practice and part-time Faculty, Universidade Estadual Paulista (UNESP), Department of Pediatric Dentistry, School of Dentistry, Araraquara, São Paulo, Brazil.
How to cite this article: Vieira CIV, Reis JMSN, Vaz LG, Martins LP, Martins RP. Deformation of nickel-titanium closed coil springs: an in vitro study. Dental Press J Orthod. 2017 Jan-Feb;22(1):38-46.

DOI: http://dx.doi.org/10.1590/2177-6709.22.1.038-046.oar

Submitted: February 17, 2016 - Revised and accepted: June 24, 2016

" The authors report no commercial, proprietary or financial interest in the products or companies described in this article.

» Patients displayed in this article previously approved the use of their facial and intraoral photographs.

Contact address: Renato Parsekian Martins

E-mail: dr_renatopmartins@hotmail.com 


\section{INTRODUCTION}

In the late 1960s, the U.S. Navy developed a nickel-titanium alloy known as Nitinol, ${ }^{1}$ which had the property of returning to its original shape after being heated above a certain temperature. This property was called "shape memory." Nitinol was introduced in Orthodontics in the 1970s, ${ }^{2}$ due to its low elastic modulus and good elastic recovery. In the following decade, two new nickel-titanium alloys ${ }^{3,4}$ were introduced in Orthodontics, bringing up a new property to orthodontic therapy: superelasticity (SE).

$\mathrm{SE}$ is characterized by a near-to-constant force (during unloading) depicted on the alloy's load/deflection graph, caused by a stress-induced transformation from austenitic to martensitic phase (SIMT), which are two different crystallographic structures that can exist within the same alloy. The image of this near-to-constant force on the graph is referred to as a plateau because of its shape, but it will be termed pseudo-plateau in this paper because it is not completely flat. Each of those two phases has a different elastic modulus, which makes this alloy unique. ${ }^{5,6,7}$ In Orthodontics, it is often desired for nickel-titanium springs to work in its SE plateau, but a high stress is needed to induce SIMT. However, the literature is not clear on how much these springs need to be activated without suffering any significant permanent deformation. There are reports in the literature, without presenting any evidence, of activations of 500\% the spring's original length without permanent deformation, ${ }^{8,9,10}$ although imposing no limits to a higher activation. Only one paper ${ }^{11}$ mentions ruptures in nickel-titanium springs excessively activated, but it does not correlate the rupture to the effective length of the nickel-titanium portion in the spring.

Currently, springs are available in different sizes and several martensitic plateaus, as informed by the manufacturer. This makes the choice for the ideal device for each situation very difficult, especially regarding the size of orthodontic space, force produced, amount of activation and the limit that each device allows for activation without permanent deformation.

Therefore, the aim of this study was to determine the percentage of deformation of four com- mercially available nickel-titanium closed coil springs subjected to several activations.

\section{MATERIAL AND METHODS}

Four groups of springs were established according to the manufacturer: Group 1, Morelli Ortodontia (Sorocaba/SP, Brazil); Group 2, Orthometric (Orthometric Importadora Exportadora Ltda, Marília/SP, Brazil); Group 3, Ormco Co. (Glendora, Ca, USA); and Group 4, Dentsply GAC Int. (Bohemia, NY, USA). Within each group, subgroups of ten springs were determined according to length and force plateau provided by the manufacturer. All ten springs from each subgroup were from the same batch, totaling 130 springs (Table 1).

An EMIC DL2000 (São José dos Pinhais, Paraná, Brazil) universal testing machine equipped with load cell of $0.1 \mathrm{kN}$ was used for testing. The entire system was submerged in distilled water at $37 \pm 1{ }^{\circ} \mathrm{C},{ }^{12}$ controlled with a $30-\mathrm{W}$ heater (Termodelfim, São Paulo, Brazil) and a thermostat (Alife, São Paulo, Brazil).

The size of the springs in each group was measured with a digital caliper (Mitutoyo SC-6, Suzano, São Paulo, Brazil) and the averages were calculated to determine the total size of the spring $(\mathrm{X})$, as well as the effective length of the nickel-titanium portion (Y) (Fig 1).

Previously to testing, each spring was adjusted with the aid of a digital indicator of extension and force in order to avoid any looseness of the spring, compromising the true activation of the spring in the test.

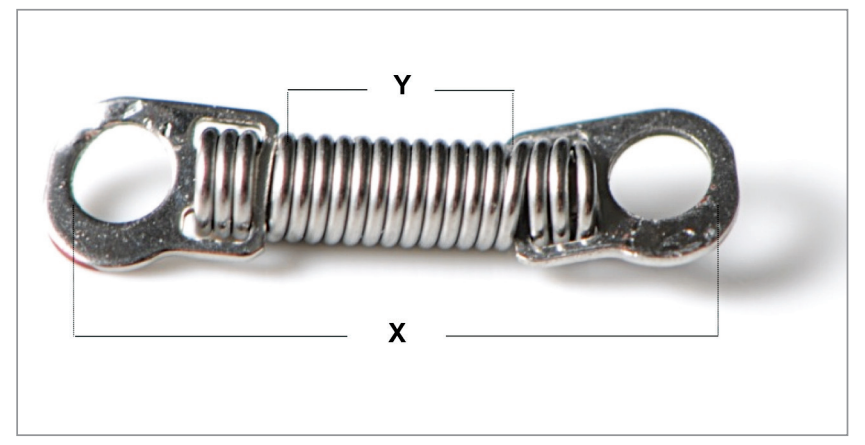

Figure 1 - Nickel-titanium closed coil spring, the $X$ dimension corresponds to the total length of the spring and the $Y$ dimension corresponds to the length of the nickel-titanium portion. 
Table 1 - Commercial brands and groups division.

\begin{tabular}{|c|c|c|c|c|c|c|c|}
\hline Commercial brand & Specification & Length $(\mathrm{mm})^{*}$ & $X(\mathrm{~mm})$ & $Y(m m)$ & Force plateau (gf)* & Subgroup & n \\
\hline \multirow{2}{*}{$\begin{array}{c}\text { Group } 1 \\
\text { (Morelli Ortodontia, Brazil) }\end{array}$} & & 7 & 8.6 & 2.3 & 250 & $1 \mathrm{~A}$ & 10 \\
\hline & & 9 & 10.3 & 3.9 & 250 & $1 \mathrm{~B}$ & 10 \\
\hline \multirow{2}{*}{$\begin{array}{c}\text { Group } 2 \\
\text { (Orthometric, Brazil) }\end{array}$} & & 7 & 6.8 & 2.1 & 175 & $2 \mathrm{~A}$ & 10 \\
\hline & & 9 & 8.9 & 4.1 & 250 & $2 \mathrm{~B}$ & 10 \\
\hline \multirow{2}{*}{$\begin{array}{c}\text { Group } 3 \\
\text { (Ormco, USA) }\end{array}$} & Light & 9 & 8.85 & 3.25 & 80 & $3 A$ & 10 \\
\hline & Heavy & 9 & 9 & 3.1 & 150 & 3B & 10 \\
\hline \multirow{7}{*}{$\begin{array}{c}\text { Group } 4 \\
\text { (GAC, USA) }\end{array}$} & Sentalloy 25g & 10 & 8.5 & 3.2 & 25 & $4 \mathrm{~A}$ & 10 \\
\hline & Sentalloy 50g & 10 & 8.5 & 3.2 & 50 & $4 \mathrm{~B}$ & 10 \\
\hline & Sentalloy $100 \mathrm{~g}$ & 10 & 8.5 & 3.2 & 100 & $4 C$ & 10 \\
\hline & Sentalloy $150 \mathrm{~g}$ & 10 & 8.5 & 3.2 & 150 & $4 \mathrm{D}$ & 10 \\
\hline & Sentalloy $200 \mathrm{~g}$ & 10 & 8.5 & 3.2 & 200 & $4 \mathrm{E}$ & 10 \\
\hline & Sentalloy $250 \mathrm{~g}$ & 10 & 8.5 & 3.2 & 250 & $4 \mathrm{~F}$ & 10 \\
\hline & Sentalloy 300g & 10 & 8.5 & 3.2 & 300 & $4 G$ & 10 \\
\hline
\end{tabular}

* information supplied by manufacturer.

The springs were activated to $100 \%$ of Y, and then returned to their original position. The test continued to 200\%, 300\%, 400\%, 500\%, 600\%, 700\%, 800\%, 900\%, 1000\% of Y. A dedicated software (EMIC - Equipamentos e Sistemas de Ensaio Ltda, São José dos Pinhais, PR, Brazil) registered, in raw format, the force values obtained throughout the trial. The test was performed at $20 \mathrm{~mm} / \mathrm{min}$.

The data obtained were exported to Microsoft Office Excel 2007 (Microsoft, Redmond, USA) in which the amount of deformation was graphically identified at each activation. Deformations were only assessed in the subgroups at the activation that presented SE behavior, as determined according to the methods described in the literature. ${ }^{13}$

Deformation values were transferred to SPSS ${ }^{\mathrm{TM}}$ software, v. 16.0 (Chicago, Illinois, USA) in which analysis of variance was carried out in order to identify differences between groups, followed by Tukey's post-hoc test to compare subgroups, since data were normally distributed.

\section{RESULTS}

Deformations of subgroup 1A springs from 400\% to $700 \%$ of activation of $\mathrm{Y}$ were similar; deformations at $800 \%$ of activation were larger than the activations from 400 to $600 \%$, but similar to $700 \%$; while deformations at $900 \%$ and $1000 \%$ of activation were the same, but different from all others activations; there was no rupture to these springs. In subgroup $1 \mathrm{~B}$, deformations at $400 \%$ to $800 \%$ of activation were the same; deformation at $800 \%$ of activation was the same as $900 \%$ of activation, which was equal to $1000 \%$ of activation; in this subgroup, one spring ruptured at $1000 \%$ activation (Table 2 ).

Deformations of subgroup 2A springs occurring from $400 \%$ to $700 \%$ of activation were similar; deformations at $800 \%$ were different from those that occurred from 400 to $600 \%$ of activation, but similar to those at $700 \%$ of activation; above $800 \%$ of activation deformations were similar; one spring ruptured at $800 \%$ of activation, two at $900 \%$, and three at $1000 \%$. In subgroup $2 \mathrm{~B}$, from $400 \%$ to $600 \%$ of activation, deformations were the same; deformation caused at 600\% was equal to the one caused at 700\%; at 800\% of activation, deformation was equal to $700 \%$ of activation; five springs ruptured at $800 \%$ of activation, four at $900 \%$, and one at $1000 \%$ of activation (Table 3).

Deformations caused at $400 \%$ to $700 \%$ of activation in subgroup $3 \mathrm{~A}$ were equal, but different from deformations that occurred at $800 \%$ to $1000 \%$ of activation, which were equal to each other; five springs ruptured at $900 \%$ of activation; from the five springs remaining, two ruptured at $1000 \%$ of activation and 
tree remained intact. Subgroup 3B did not show SE behavior, so no comparison was performed. In subgroup 3C, deformations that occurred at 600\% to $800 \%$ of activation were equal, with deformation at $800 \%$ being the same as the deformation at $900 \%$ of activation, which was the same deformation that occurred at $1000 \%$ of activation; four springs of this subgroup ruptured at $1000 \%$ of activation (Table 4).

In subgroup $4 \mathrm{~A}$, deformations that occurred at $400 \%$ to $800 \%$ of activation were equal to each other and different from deformations occurring at $900 \%$ and at $1000 \%$ of activation, which were equal.
In subgroups $4 \mathrm{~B}, 4 \mathrm{D}, 4 \mathrm{C}$, and $4 \mathrm{E}$, all deformations were the same at $400 \%$ to $1000 \%$ of activation for the first two subgroups, at 300\% to $1000 \%$ of activation for subgroup $4 \mathrm{C}$, and at $500 \%$ to $1000 \%$ of activation for $4 \mathrm{E}$. In subgroup $4 \mathrm{~F}$, deformations were equal at $400 \%$ to $800 \%$ of activation, but different at $900 \%$ and $1000 \%$. In subgroup 4G, deformations were equal at $500 \%$ to $800 \%$ and different at $900 \%$ and $1000 \%$. None of the springs in subgroups 4A, 4B, 4C, 4D, 4E, and 4F ruptured. Only one spring in subgroup $4 \mathrm{G}$ ruptured at $900 \%$ of activation and two springs at $1000 \%$ (Table 5).

Table 2 - Average deformation in millimeters (SD in parenthesis) and in percentage values of the total length of group 1 springs.

\begin{tabular}{|c|c|c|c|c|c|c|}
\hline \multirow{3}{*}{ Activation } & \multirow{2}{*}{\multicolumn{3}{|c|}{$\begin{array}{l}\text { Subgroup 1A } \\
\text { Deformation }\end{array}$}} & \multicolumn{3}{|c|}{ Subgroup $1 \mathrm{~B}$} \\
\hline & & & & & formati & \\
\hline & $n$ & $\%$ & mm & $n$ & $\%$ & $\mathrm{~mm}$ \\
\hline $400 \%$ & 10 & $2.6 \%$ & $0.06(0.05)^{A}$ & 10 & $1.3 \%$ & $0.05(0.07)^{A}$ \\
\hline $500 \%$ & 10 & $3.9 \%$ & $0.09(0.05)^{A}$ & 10 & $3.1 \%$ & $0.12(0.08)^{A}$ \\
\hline $600 \%$ & 10 & $3.9 \%$ & $0.09(0.11)^{A}$ & 10 & $5.6 \%$ & $0.22(0.18)^{A}$ \\
\hline $700 \%$ & 10 & $9.1 \%$ & $0.21(0.09)^{A B}$ & 10 & $7.7 \%$ & $0.30(0.33)^{A}$ \\
\hline $800 \%$ & 10 & $17.4 \%$ & $0.40(0.18)^{\mathrm{B}}$ & 10 & $16.4 \%$ & $0.64(0.50)^{A B}$ \\
\hline $900 \%$ & 10 & $29.6 \%$ & $0.68(0.26)^{c}$ & 10 & $36.4 \%$ & $1.42(0.68)^{B C}$ \\
\hline $1000 \%$ & 10 & $35.2 \%$ & $0.81(0.36)^{c}$ & 9 & $55.9 \%$ & $2.18(1.28)^{c}$ \\
\hline$p$ & & $<0.001$ & & & $<0.001$ & \\
\hline
\end{tabular}

Table 3 - Average deformation in millimeters (SD in parenthesis) and in percentage values of group 2 springs.

\begin{tabular}{|c|c|c|c|c|c|c|}
\hline \multirow[t]{2}{*}{ Activation (\%) } & \multicolumn{3}{|c|}{$\begin{array}{l}\text { Subgroup 2A } \\
\text { Deformation }\end{array}$} & \multicolumn{3}{|c|}{$\begin{array}{l}\text { Subgroup 2B } \\
\text { Deformation }\end{array}$} \\
\hline & $n$ & $\%$ & mm & $\mathbf{n}$ & $\%$ & mm \\
\hline $400 \%$ & 10 & $10.0 \%$ & $0.21(0.18)^{A}$ & 10 & $6.6 \%$ & $0.27(0.18)^{A}$ \\
\hline $500 \%$ & 10 & $13.8 \%$ & $0.29(0.24)^{A}$ & 10 & $14.4 \%$ & $0.59(0.26)^{A}$ \\
\hline $600 \%$ & 10 & $15.7 \%$ & $0.33(0.28)^{A}$ & 10 & $22.4 \%$ & $0.92(0.37)^{\mathrm{AB}}$ \\
\hline $700 \%$ & 10 & $36.2 \%$ & $0.76(0.38)^{A B}$ & 10 & $36.8 \%$ & $1.51(0.84)^{\mathrm{BC}}$ \\
\hline $800 \%$ & 9 & $66.2 \%$ & $1.39(0.68)^{B C}$ & 5 & $44.1 \%$ & $1.81(0.63)^{c}$ \\
\hline $900 \%$ & 7 & $96.7 \%$ & $2.03(0.84)^{c}$ & 1 & $81.2 \%$ & 3.33 \\
\hline $1000 \%$ & 4 & $102.4 \%$ & $2.15(1.74)^{\mathrm{C}}$ & 0 & - & - \\
\hline p & & $<0.001$ & & & $<0.001$ & \\
\hline
\end{tabular}


Table 4 - Average deformation in millimeters (SD in parenthesis) and in percentage values of the total length of group 3 springs.

\begin{tabular}{|c|c|c|c|c|c|c|}
\hline \multirow{3}{*}{ Activation (\%) } & \multicolumn{3}{|c|}{ Subgroup 3A } & \multicolumn{3}{|c|}{ Subgroup 3C } \\
\hline & & eformati & & & format & \\
\hline & $\mathbf{n}$ & $\%$ & $\mathrm{~mm}$ & n & $\%$ & $\mathrm{~mm}$ \\
\hline $300 \%$ & 10 & $3.7 \%$ & $0.12(0.08)^{A}$ & - & - & - \\
\hline $400 \%$ & 10 & $6.5 \%$ & $0.21(0.10)^{A}$ & - & - & - \\
\hline $500 \%$ & 10 & $9.5 \%$ & $0.31(0.16)^{A}$ & - & - & - \\
\hline $600 \%$ & 10 & $17.5 \%$ & $0.57(0.23)^{A}$ & 10 & $17.7 \%$ & $0.55(0.24)^{A}$ \\
\hline $700 \%$ & 10 & $42.1 \%$ & $1.37(0.37)^{\mathrm{A}}$ & 10 & $31.6 \%$ & $0.98(0.39)^{A}$ \\
\hline $800 \%$ & 10 & $107.1 \%$ & $3.48(1.58)^{\mathrm{B}}$ & 10 & $66.1 \%$ & $2.05(1.05)^{A}$ \\
\hline $900 \%$ & 5 & $147.1 \%$ & $4.78(0.98)^{\mathrm{B}}$ & 10 & $120.0 \%$ & $3.72(1.81)^{\mathrm{B}}$ \\
\hline $1000 \%$ & 3 & $137.5 \%$ & $4.47(3.67)^{\mathrm{B}}$ & 6 & $154.5 \%$ & $4.79(1.38)^{\mathrm{B}}$ \\
\hline$p$ & & $<0.001$ & & & $<0.001$ & \\
\hline
\end{tabular}

- Non SE.

Table 5 - Average deformation in millimeters (SD in parenthesis) and in percentage values of the total length of group 4 springs.

\begin{tabular}{|c|c|c|c|c|c|c|c|c|c|c|c|c|}
\hline \multirow{3}{*}{ Activation } & \multicolumn{3}{|c|}{ Subgroup 4A } & \multicolumn{3}{|c|}{ Subgroup 4B } & \multicolumn{3}{|c|}{ Subgroup 4C } & \multicolumn{3}{|c|}{ Subgroup 4D } \\
\hline & \multicolumn{3}{|c|}{ Deformation } & \multicolumn{3}{|c|}{ Deformation } & \multicolumn{3}{|c|}{ Deformation } & \multicolumn{3}{|c|}{ Deformation } \\
\hline & n & $\%$ & $\mathrm{~mm}$ & $\mathbf{n}$ & $\%$ & $\mathrm{~mm}$ & n & $\%$ & $\mathrm{~mm}$ & n & $\%$ & $\mathrm{~mm}$ \\
\hline $300 \%$ & - & - & - & - & - & - & 10 & $2.2 \%$ & $0.07(0.05)$ & - & - & - \\
\hline $400 \%$ & 10 & $3.4 \%$ & $0.11(0.09)^{A}$ & 10 & $2.2 \%$ & $0.07(0.05)$ & 10 & $2.2 \%$ & $0.07(0.06)$ & 10 & $3.4 \%$ & $0.10(0.07)$ \\
\hline $500 \%$ & 10 & $2.5 \%$ & $0.08(0.05)^{A}$ & 10 & $2.2 \%$ & $0.07(0.06)$ & 10 & $2.5 \%$ & $0.08(0.05)$ & 10 & $4.1 \%$ & $0.13(0.13)$ \\
\hline $600 \%$ & 10 & $3.4 \%$ & $0.10(0.12)^{A}$ & 10 & $2.2 \%$ & $0.07(0.06)$ & 10 & $2.5 \%$ & $0.08(0.06)$ & 10 & $4.1 \%$ & $0.13(0.13)$ \\
\hline $700 \%$ & 10 & $2.8 \%$ & $0.11(0.08)^{A}$ & 10 & $2.2 \%$ & $0.07(0.06)$ & 10 & $2.5 \%$ & $0.08(0.06)$ & 10 & $3.4 \%$ & $0.10(0.12)$ \\
\hline $800 \%$ & 10 & $14.0 \%$ & $0.45(0.29)^{A}$ & 10 & $1.6 \%$ & $0.05(0.05)$ & 10 & $2.5 \%$ & $0.08(0.04)$ & 10 & $3.4 \%$ & $0.10(0.12)$ \\
\hline $900 \%$ & 10 & $59.7 \%$ & $1.91(1.02)^{\mathrm{B}}$ & 10 & $1.3 \%$ & $0.04(0.04)$ & 10 & $1.3 \%$ & $0.04 *(0.07)$ & 10 & $3.8 \%$ & $0.12(0.19)$ \\
\hline $1000 \%$ & 10 & $44.1 \%$ & $1.41(0.96)^{\mathrm{B}}$ & 10 & $-0.6 \%$ & $-0.02(0.14)$ & 10 & $1.3 \%$ & $0.04 *(0.25)$ & 10 & $2.8 \%$ & $0.09 *(0.19)$ \\
\hline$p$ & \multicolumn{3}{|c|}{$<0.001$} & \multicolumn{3}{|c|}{0.076} & \multicolumn{3}{|c|}{0.965} & \multicolumn{3}{|c|}{0.981} \\
\hline \multirow{3}{*}{ Activation } & \multicolumn{3}{|c|}{ Subgroup 4E } & \multicolumn{3}{|c|}{ Subgroup 4F } & \multicolumn{3}{|c|}{ Subgroup 4G } & & & \\
\hline & \multicolumn{3}{|c|}{ Deformation } & \multicolumn{3}{|c|}{ Deformation } & \multicolumn{3}{|c|}{ Deformation } & & & \\
\hline & $\mathbf{n}$ & $\%$ & $\mathrm{~mm}$ & $\mathbf{n}$ & $\%$ & $\mathrm{~mm}$ & $n$ & $\%$ & $\mathrm{~mm}$ & & & \\
\hline $300 \%$ & - & - & - & - & - & - & - & - & - & & & \\
\hline $400 \%$ & - & - & - & 10 & $4.1 \%$ & $0.13(0.05)^{A}$ & - & - & - & & & \\
\hline $500 \%$ & 10 & $1.6 \%$ & $0.05(0.04)$ & 10 & $4.1 \%$ & $0.13(0.07)^{A}$ & 10 & $3.4 \%$ & $0.10(0.09)^{\AA}$ & & & \\
\hline $600 \%$ & 10 & $0.6 \%$ & $0.02(0.03)$ & 10 & $3.8 \%$ & $0.12(0.08)^{A}$ & 10 & $3.4 \%$ & $0.10(0.08)^{A}$ & & & \\
\hline $700 \%$ & 10 & $0.9 \%$ & $0.03(0.03)$ & 10 & $3.4 \%$ & $0.11(0.06)^{A}$ & 10 & $1.6 \%$ & $0.05(0.05)^{A}$ & & & \\
\hline $800 \%$ & 10 & -0.01 & $-0.02^{\star}(0.18)$ & 10 & $0.9 \%$ & $0.03^{*}(0.07)^{A}$ & 10 & $0.9 \%$ & $0.03^{*}(0.86)^{A}$ & & & \\
\hline $900 \%$ & 10 & $1.6 \%$ & $0.05^{\star}(0.27)$ & 10 & $12.5 \%$ & $-0.4(0.23)^{\mathrm{B}}$ & 9 & $38.1 \%$ & $1.22(1.41)^{\mathrm{B}}$ & & & \\
\hline $1000 \%$ & 10 & $1.6 \%$ & $0.05 *(0.38)$ & 10 & $72.5 \%$ & $2.32(0.66)^{c}$ & 7 & $89.7 \%$ & $2.87(1.11)^{c}$ & & & \\
\hline$p$ & \multicolumn{3}{|c|}{0.975} & \multicolumn{3}{|c|}{$<0.001$} & \multicolumn{3}{|c|}{$<0.001$} & & & \\
\hline
\end{tabular}

* Non significant values.

- Non SE.

\section{DISCUSSION}

All springs tested could be activated up to 700\% without rupturing, some subgroups however, showed more resistance to rupture. Springs in subgroups 1A, 4A, 4B, 4C, 4D, 4E, and 4F did not rupture up to the length tested, while the ones in subgroups $1 \mathrm{~B}, 3 \mathrm{~B}$, and $4 \mathrm{G}$ only ruptured at $1000 \%$ of activation. Springs of subgroup $3 \mathrm{~A}$ began to rupture at $900 \%$, and the ones in Group 2 began to rupture at $800 \%$ of activation. Comparison of these values is difficult because the literature mentions activations only up to $500 \%,,^{8,9,10}$ and only one study ${ }^{11}$ tested springs until they ruptured. In this last study, however, activations were not correlated to the percentage of activation in relation to Y. Despite the risk of rupture being one of the determinant factors to how much a spring can be activated, there are other more important factors, such as deformation. 
In most springs of Groups 1, 2, and 3, there was no difference between deformation up to $700 \%$ of activation. From that percentage of activation on, deformations increased (except for subgroups 2B and 3C). Even at the smallest activations where SIMT occurred (mostly at 400\%), there was already a small deformation that remained stable until $700 \%$ of activation, which could be due to stress relaxation of the springs. An interesting fact is that all springs in groups 1 and 2 showed resistance to rupture up to approximately $36 \%$ of deformation, and started to rupture above that amount. Deformations measured by this research in nickel-titanium springs may have happened partially because of stress relaxation, residual permanent deformation, ${ }^{14}$ and reversible martensitic deformation, which is reversible upon heating above a certain temperature, due to shape memory (Fig 2).

Springs in group 4 ruptured and deformed less than in other groups. In subgroups $4 \mathrm{~B}, 4 \mathrm{C}, 4 \mathrm{D}$, and $4 \mathrm{E}$, deformation was the same in all activations, even at $1000 \%$ of activation, deformations were not clinically significant and were smaller than $2.8 \%$. Subgroups $4 \mathrm{~A}$, $4 \mathrm{~F}$, and $4 \mathrm{G}$ showed the same amount of deformation up to $800 \%$ of activation, with maximum deformations of $14 \%, 0.9 \%$, and $0.9 \%$, respectively. It is clear that, even with a subjective assessment, springs in group 4 were superior when compared to the ones in other groups in relation to deformation and resistance. Similarly to springs of groups 1 and 2, springs of subgroup 4G started to rupture above $38 \%$ of deformation.

From a clinical standpoint, even with significant deformations of about 30\%, some springs could still be efficient depending on the situation they are used. When closing pre-molars spaces (Fig 3), nickel-titanium springs are normally attached from hooks on the first molars to hooks on the canines (around $23 \mathrm{~mm}$ of distance), ${ }^{15}$ and after a $7 \mathrm{~mm}$ space closure, they would still be active over the $16-\mathrm{mm}$ space left. Thus, if a spring of subgroup $1 \mathrm{~A}(8.6 \mathrm{~mm}$ in total length) is attached to the molar hook, stretched to $900 \%$ and then engaged over the hook of the archwire during deactivation, it would be effectively activated $14.4 \mathrm{~mm}$ and it would remain active up to $7.4 \mathrm{~mm}$ of activation with constant force. With a slight difference, one spring from subgroup 1B $(10.3 \mathrm{~mm})$ would be active from 12.7 to $5.7 \mathrm{~mm}$ (Fig 4 ). In those two clinical situations, deformations smaller than $7.4 \mathrm{~mm}$ and
$5.7 \mathrm{~mm}$, respective to each situation, would be considered clinically irrelevant. However, there are two other variables that should be considered when using nickel-titanium springs: one is the desired force, since the force plateau decreases with increased activation; ${ }^{11,16}$ and the second is the relationship between the spring's clinical work range (Fig 3) and the SE plateau length, because even at a SIMT, the dimensions that are clinically used in Orthodontics could make the spring work outside its SE plateau (Fig 4), thus acting in a SE way only after some space is closed or even never acting in a SE way at all.

The decrease of inclination and increase of length in force plateau with activation occurs because stress in not evenly distributed throughout the spring with activation. As activation is gradually increased, there is a tendency for more areas of the spring to be stressed enough to produce a SIMT; thus, with more areas going through reverse transformation, more "superelastic" the spring becomes. For that reason, limiting nickel-titanium springs activation with the purpose of maintaining forces at a low level is illogical. Moreover, it appears to be a good idea to overactivate those springs upon affixation, in order to improve the springs ability to produce constant and relatively lower forces. ${ }^{17}$ That directly connects to the fact that the vast majority of nickel-titanium materials does not behave in a superelastic manner when used in Orthodontics, due to the fact that they are not activated enough to produce SIMT. Large springs will not work properly since not enough stress is produced (Fig 5): ${ }^{17}$ thus, a pseudo-pla-

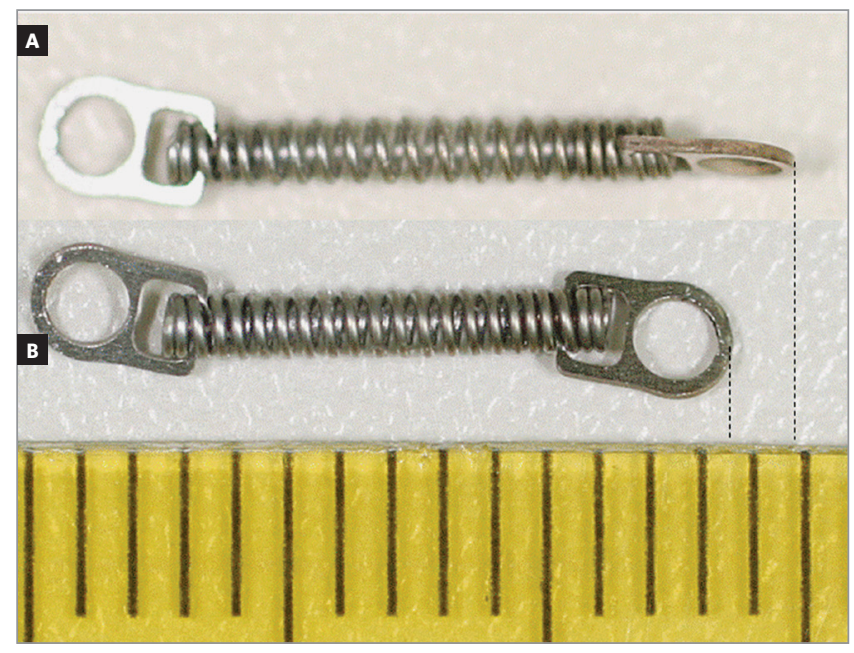

Figure 2 - Nickel-titanium closed coil spring, before activation (B) and after $900 \%$ of activation (A). After heating it above a certain temperature (Af), the martensitic deformation will resume due to the shape memory effect. 

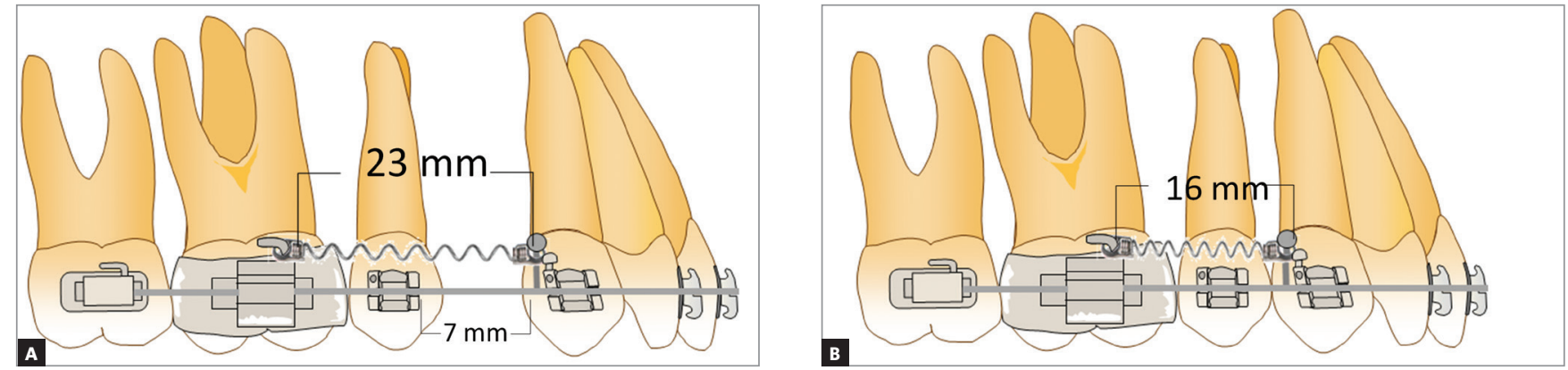

Figure 3 - Space closure after extraction of first premolars where a nickel titanium spring was attached to a hook from the first molar to a hook distal to the canine ( $23 \mathrm{~mm}$ distance), remaining active even after space closure (minus $7 \mathrm{~mm}$ of pre-molar space).
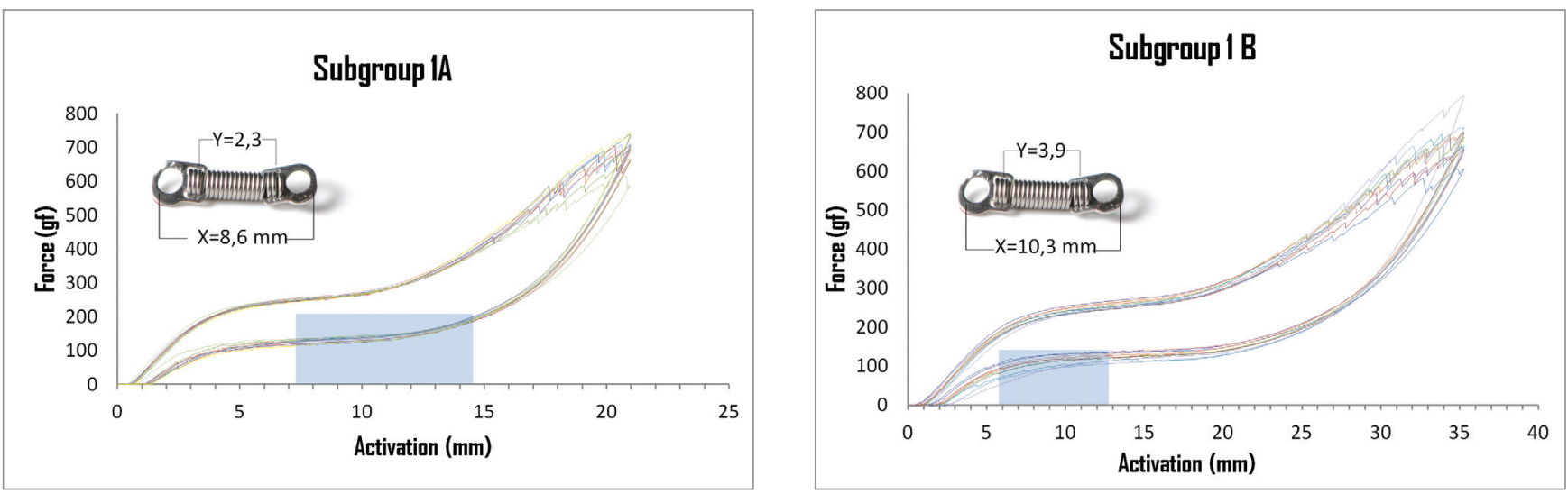

Figure 4 - A) Load/deflection graph for the springs of the subgroup $1 \mathrm{~A}$ activated at $900 \%$ of $Y(20.7 \mathrm{~mm}$ of activation or $29.3 \mathrm{~mm}$ if the size of the spring is accounted). The blue box corresponds to the distance between the hook of the first molar and a hook distal to the upper canine (minus size of the spring). as in Figure $3(23 \mathrm{~mm}$ minus X). Note that to take full advantage of the springs' SE properties, an increase of approximately $3 \mathrm{~mm}$ in the eyelets (not in nickel titanium portion) would be required in order to maintain the force in the SE plateau. That would shift the blue box to the left the same 3mm. B) Same situation on the subgroup 1B, however, full SE capability would not be achieved in last $2 \mathrm{~mm}$ or so of space closure, since the force would start to decrease due to lack of stress.

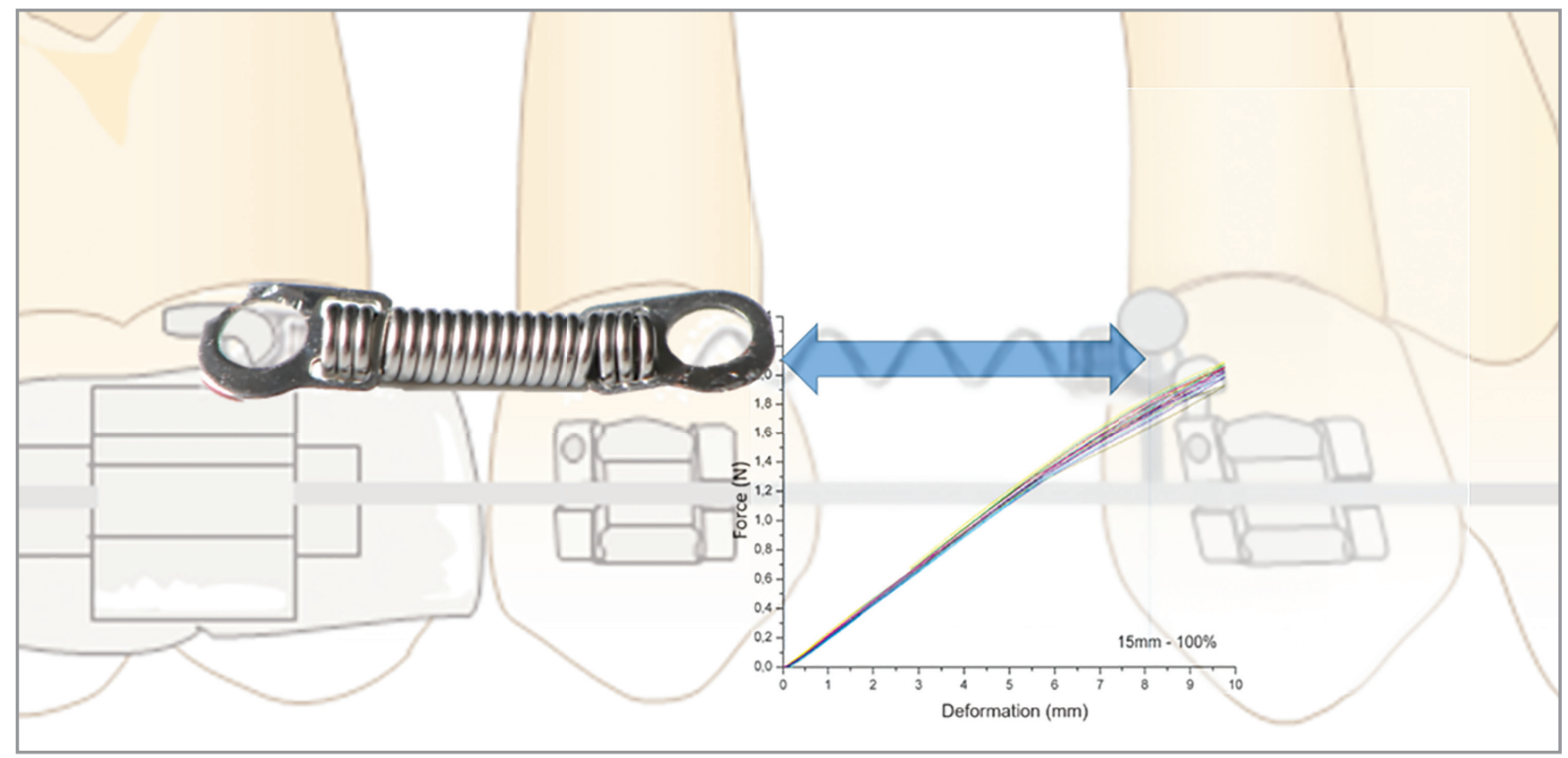

Figure 5 - A 15-mm long nickel-titanium spring (nickel-titanium portion with $9.8 \mathrm{~mm}$ ), activated $9.8 \mathrm{~mm}$. A spam of activation from the hook of a first molar to the canine, from $23 \mathrm{~mm}$ to $16 \mathrm{~mm}$ (similar to Figure 3), is shown by the blue arrow. In this case, due to the springs length, that activation would account $8 \mathrm{~mm}$, deactivating to $1 \mathrm{~mm}$ after space closure. Note that no superelasticity will not exist in this spring at this activation. 


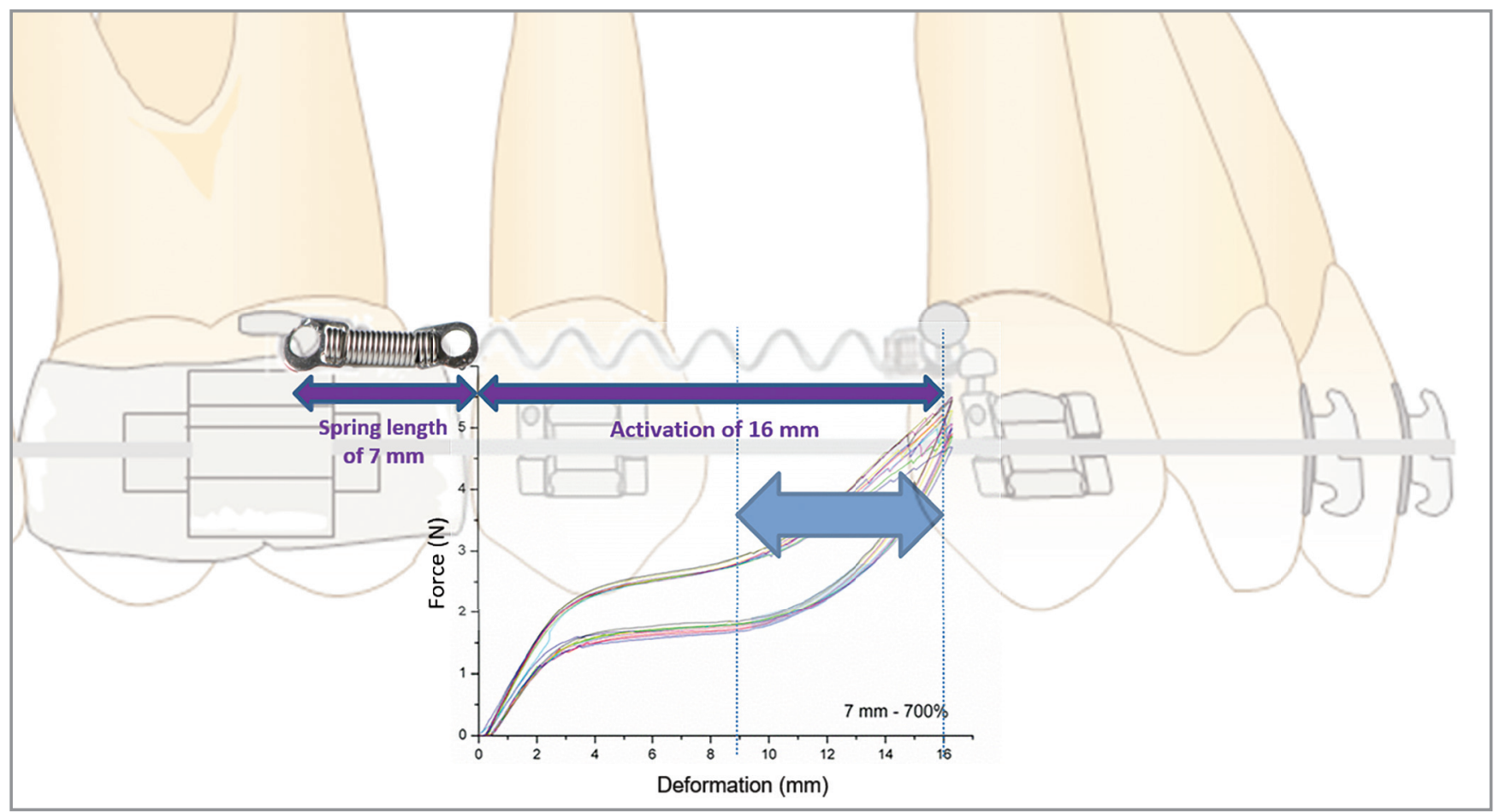

Figure 6 - A 7-mm long nickel-titanium spring (2.3mm of nickel-titanium portion) activated approximately $16 \mathrm{~mm}$, which would result in an activation of $23 \mathrm{~mm}$ It can be observed that due to the shape of the load-deflection graph, the pseudo-plateau area, or the near-to-constant force, of the spring would not be used during a $7 \mathrm{~mm}$ space closure.

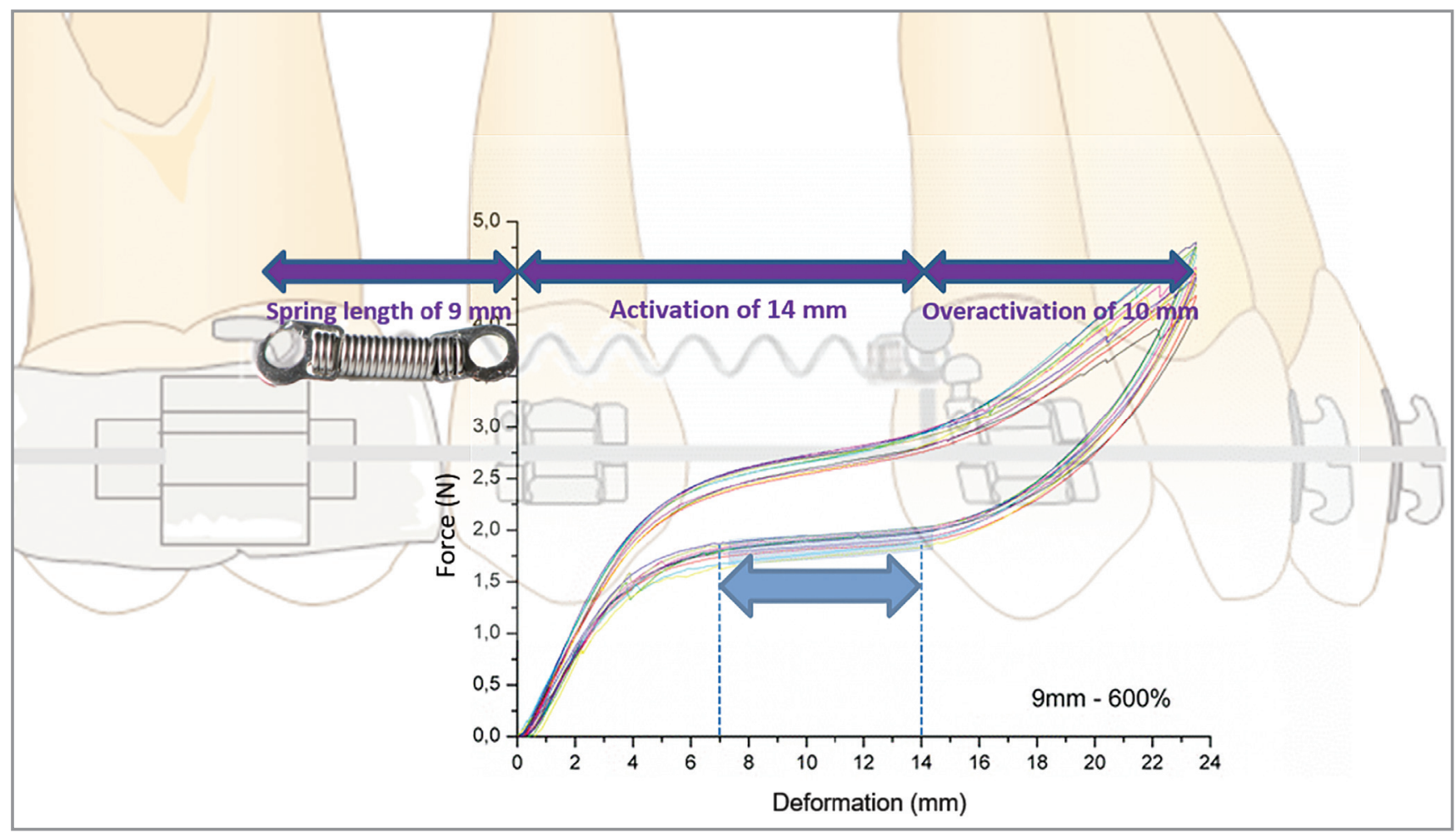

Figure 7 - A 9-mm long nickel-titanium spring (3.9mm of nickel-titanium portion) activated 23.4mm, or $600 \%$ the length of its SE material. A spam of activation from $14 \mathrm{~mm}$ to $7 \mathrm{~mm}$ is shown by the blue arrow. Note that a pseudo-plateau can be used in this situation only if the spring is overactivated $10 \mathrm{~mm}$ beyond its affixation. The amount of overactivation will depend on the spring's total length, the length of nickel-titanium portion, and the interbracket distance. 
teau is not produced. Even if SIMT is achieved when a shorter spring is used (Fig 6), there is a sudden drop of force in the beginning of reverse transformation, which would not allow constant force. The spring in this situation could be very flexible, but not superelastic on that 7-mm range of activation. The solution would be either to produce a longer spring, adding to the eyelets and not to the nickel-titanium portion, ${ }^{17}$ or to overactivate the springs, as already mentioned (Fig 7). That would allow a window of activation which would use a long enough pseudo-plateau during space closure, escaping from the sudden drop of force, as depicted by Figure 6. Activating the spring only up to $14 \mathrm{~mm}$, and not overactivating it on this particular situation (Fig 7), would include the sudden drop of force characteristically seen in the beginning of the reverse SIMT up to $7 \mathrm{~mm}$ of deactivation spam, similar to what is shown in Figure 6. The force, therefore, would not be as continuous as the one produced when overactivating the spring during space closure.

All springs were tested at $37^{\circ} \mathrm{C}$, as mentioned in the Methods section, according to the American Dental Association specification of 2006. ${ }^{12}$ That was necessary because shape-memory alloys respond differently to a given temperature ${ }^{14,18}$ and, therefore, it was the objective of this paper to know how nickel-titanium closed coil springs would deform at mouth temperature. When one of those alloys, nickel-titanium included, is below its Af temperature, some martensite is stable and will allow deformation that would not exist at a higher temperature; i.e., above Af. Even though the springs were tested at $37^{\circ} \mathrm{C}$, not all characteristics of the oral cavity could be mimicked, which is one of the limitations of this study. This is important because it is known that the oral cavity could contribute further to the deformation of springs. ${ }^{19}$

\section{CONCLUSIONS}

" The majority of springs had a similar amount of deformation from the moment they became superelastic, from around 400\% of activation up to 700\% of activation, in relation to the length of the nickeltitanium portion present in the closed coil springs, without rupturing.

"Subgroups 4B, 4C, 4D, and 4E had a similar amount of deformation up to $1000 \%$ of activation (32 $\mathrm{mm})$ without rupturing.

\section{Author contributions}

Conception or design of the study: JMSNR, LGV, LPM. Data acquisition, analysis or interpretation: CIVV, JMSNR, LGV. Writing the article: CIVV, RPM. Critical revision of the article: LGV, LPM. Final approval of the article: JMSNR, LPM, RPM. Obtained funding: CIVV, LPM. Overall responsibility: RPM.

1. Buehler WJ, Wiley RC. TiNi-Ductile intermetallic compound. Trans ASM 1962:55:269-76.

2. Andreasen GF, Hilleman TB. An evaluation of 55 cobalt substituted Nitinol wire for use in orthodontics. J Am Dent Assoc. 1971 June;82(6):1373-5

3. Burstone CJ, Qin B, Morton JY. Chinese NiTi wire--a new orthodontic alloy. Am J Orthod. 1985 Jun;87(6):445-52.

4. Miura F, Mogi M, Ohura Y, Hamanaka H. The super-elastic property of the Japanese NiTi alloy wire for use in orthodontics. Am J Orthod Dentofacial Orthop. 1986 July; 90(1):1-10.

5. Miura F, Mogi M, Ohura Y. Japanese NiTi alloy wire: use of the direct electric resistance heat treatment method. Eur J Orthod. 1988 Aug:10(3):187-91.

6. Khier SE, Brantley WA, Fournelle RA. Bending properties of superelastic and nonsuperelastic nickel-titanium orthodontic wires. Am J Orthod Dentofacial Orthop. 1991;99(4):310-8.

7. Gangbing KB, Agrawal BN, Lam PC, Srivatsan TS. Application of shape memory alloy wire actuator for precision position control of a composite beam. J Mat Eng Perf. 2000;9(3):330-3.

8. Miura F, Mogi M, Ohura Y, Karibe M. The super-elastic Japanese NiTi alloy wire for use in orthodontics. Part III. Studies on the Japanese NiTi alloy coil springs. Am J Orthod Dentofacial Orthop. 1988 Aug:94(2):89-96.

9. Manhartsberger C, Seidenbusch W. Force delivery of Ni-Ti coil springs. Am J Orthod Dentofacial Orthop. 1996 Jan;109(1):8-21

10. Tripolt H, Burstone CJ, Bantleon P, Manschiebel W. Force characteristics of nickel-titanium tension coil springs. Am J Orthod Dentofacial Orthop. 1999 May:115(5):498-507.

11. Wichelhaus A, Brauchli L, Ball J, Mertmann M. Mechanical behavior and clinical application of nickel-titanium closed-coil springs under different stress levels and mechanical loading cycles. Am J Orthod Dentofacial Orthop. 2010 May:137(5):671-8.

12. American National Standards Institute. American Dental Association. Orthodontic wires not containing precious metals specification 32. New Work: ANSI; 2006.

13. Segner D, Ibe D. Properties of superelastic wires and their relevance to orthodontic treatment. Eur J Orthod. 1995 Oct;17(5):395-402.

14. Duerig TW, Melton KN, Stockel D, Wayman CM. Engineering aspects of shape memory alloys. London: Butterworth-Heinimann; 1990.

15. Martins RP, Buschang PH, Gandini LG Jr. Group A T-loop for differential moment mechanics: an implant study. Am J Orthod Dentofacial Orthop. 2009 Feb;135(2):182-9

16. Maganzini AL, Wong AM, Ahmed MK. Forces of various nickel titanium closed coil springs. Angle Orthod. 2010 Jan;80(1):182-7.

17. Vieira Cl, Caldas SG, Martins LP, Martins RP. Superelasticity and force plateau of nickel-titanium springs: an in vitro study. Dental Press J Orthod. 2016 June:21(3):46-55.

18. Tonner RI, Waters NE. The characteristics of super-elastic Ni-Ti wires in three-point bending. Part I: The effect of temperature. Eur J Orthod. 1994 Oct:16(5):409-19.

19. Magno AF, Monini Ada C, Capela MV, Martins LP, Martins RP. Effect of clinical use of nickel-titanium springs. Am J Orthod Dentofacial Orthop. 2015 July:148(1):7682. 